\title{
In Vitro Antiviral Activity of Marine Sponges Collected Off Brazilian Coast
}

\author{
Alexandre Cordeiro da SiLVA, ${ }^{a}$ Jadel Muller Kratz, ${ }^{a}$ Fabiane Maria Farias, ${ }^{c}$ \\ Amélia Terezinha Henriques, ${ }^{c}$ Josivete dos Santos, ${ }^{d}$ Rosa Maria Leonel,${ }^{e}$ Clea Lerner,${ }^{f}$ \\ Beatriz Mothes,${ }^{f}$ Célia Regina Monte BARARDi,${ }^{b}$ and Cláudia Maria Oliveira SimõEs $*, a$ \\ ${ }^{a}$ Laboratório de Virologia Aplicada da UFSC, Departamento de Ciências Farmacêuticas, CCS, Universidade Federal de \\ Santa Catarina (UFSC); ${ }^{b}$ Laboratório de Virologia Aplicada da UFSC, Departamento de Microbiologia e Parasitologia, \\ CCB, Universidade Federal de Santa Catarina (UFSC); Campus Universitário Trindade, Florianópolis 88040-900, SC, \\ Brazil: ${ }^{c}$ Faculdade de Farmácia, Universidade Federal do Rio Grande do Sul (UFRGS); Avenida Ipiranga 2752, Porto \\ Alegre 90610-000, RS, Brazil: ${ }^{d}$ Departamento de Oceanografia, Universidade Federal de Pernambuco (UFPE); Campus \\ Universitário, Recife, 50740-550, PE, Brazil: ${ }^{e}$ Departamento de Sistemática e Ecologia, Universidade Federal da Paraíba \\ (UFPB); Campus Universitário, João Pessoa, 58059-900, PB, Brazil: and ${ }^{f}$ Fundação Zoobotânica, Museu de Ciências \\ Naturais; Rua Salvador França 1427, Porto Alegre 90690-000, RS, Brazil.
}

Received June 8, 2005; accepted August 22, 2005

This paper describes the in vitro antiviral evaluation of 27 different marine sponges (Porifera) collected off Brazilian coastline in the search for novel drug leads. With these sponges aqueous and organic extracts were prepared and tested for anti-herpetic (HSV-1, KOS strain), anti-adenovirus (human AdV serotype 5) and anti-rotavirus (simian RV SA11) activities. The evaluation of the cytotoxicity and potential antiviral activity of these extracts were performed by using MTT assay. Results were expressed as $50 \%$ cytotoxicity $\left(\mathrm{CC}_{50}\right)$ and $50 \%$ effective $\left(E_{50}\right)$ concentrations, respectively, in order to calculate the selectivity indices $\left(\mathrm{SI}=\mathrm{CC}_{50} / \mathrm{EC}_{50}\right)$ of each extract. From the 40 sponge extracts tested, 17 extracts showed antiviral action in different degrees. The results concerning the antiviral activity were obtained by using three different strategies: (1) simultaneous assay, when sponge extracts were added to the cells at the same time of the viruses; (2) pre treatment assay, when sponge extracts were added to the cells $15 \mathrm{~h}$ prior to the viruses infection; and (3) post treatment assay, when the viruses were added to the cells and remained during $2 \mathrm{~h}$ prior to the addition of sponge extracts. The antiviral assays with HSV-1/KOS and AdV-5 showed more promising results when the pre treatment test was employed. In relation to the RV-SA11 virus, only the simultaneous assay showed antiviral activity. The extracts presenting the most promising results were the aqueous extracts of Cliona sp., Agelas sp.2, Tethya sp., Axinella aff corrugata, Polymastia janeirensis and Protosuberites sp., and these extracts deserve special attention in further studies.

Key words antiviral activity; Brazilian marine sponge; MTT assay; HSV-1; adenovirus 5; rotavirus SA11

The current antiviral drug armamentarium comprises nearly 40 compounds that have been officially approved for clinical use. Most of these drugs date back the last five years, and at least half of them are used for the treatment of human immunodeficiency virus (HIV) infection. ${ }^{1)}$ Taking this situation into account, the importance of developing new antiviral agents becomes clear in order to increase the number of these available drugs.

The Herpes Simplex Viruses (HSV) are responsible for a broad range of human infectious diseases. Moreover, HSV infections were reported to be recognized as a risk factor for human immunodeficiency virus (HIV) infection. ${ }^{2)}$ However, the prolonged therapies with the available antiherpes drugs have resulted in some undesirable effects ${ }^{3)}$ and also induced the emergence of drug-resistant strains. ${ }^{4}$

The adenovirus serotype $5(\mathrm{AdV}-5)$ is very stable in the environment during long periods of time, and it is associated with respiratory infections with no specific treatment. ${ }^{5)}$

The rotaviruses are responsible for severe gastroenteritis in both humans and animals. The infection of children and/or immunocompromised patients can lead to death by diarrhea, and the treatment is only symptomatic. $\left.{ }^{6}\right)$ Therefore, it is necessary to develop new antiviral agents against these viruses.

Natural products derived from terrestrial and marine kingdoms represent an inexhaustible source of compounds with promising antiviral action, not only for the great number of species found in these kingdom with unexplored pharmacological activities, but mainly for the variety of synthesized metabolites. ${ }^{7-10)}$ The marine environment possesses an important biodiversity represented by 34 of the 36 phyla of all globe, with $c a$. of 300000 known species of plants and animals, such as sponges, tunicates, bryozoans, shellfish, bacteria, fishes, seaweeds, just to name a few. Ecological pressures, such as competition for space, predation, symbiosis and tide variations, throughout thousand of years originated the biosynthesis of complex and different secondary metabolites by these organisms, which in turn allowed their adaptation to a competitive and hostile environment. ${ }^{11-13)}$

In relation to the infectious diseases, the exploration of the marine environment represents a promising strategy in the search for active compounds, whereas there is a need for new medicines, due to the appearance of resistance to the available treatments in many microorganisms, specifically concerning antifungal, antiprotozoal, antibacterial and antiviral activities. Viruses have remained resistant to treatment or prophylaxis longer than any other infectious organisms. ${ }^{14)}$

The search for new antiviral agents from marine sources has yielded several promising therapeutic leads. The literature shows a great number of reports about different pharmacological activities of marine sponges. Many papers showed the results of the screening of marine organisms for antiviral activity, and a wide range of active compounds have been 
isolated and characterized from them. ${ }^{12-21)}$

For some of these compounds an important antiviral activity was described, such as avarol and avarone isolated from the sponge Disidea avara, which inhibited HIV virus replication, and showed the ability to cross blood-brain barrier. ${ }^{22)}$ Another example of a marine antiviral compound is the betacarboline alkaloid eudistomin, isolated from a tunicate Eudistoma ollivaceum, which, along with other related $\beta$-carbolines, has demonstrated anti-HSV-1 and 2 activity. ${ }^{23)}$ Other marine antiviral compounds are cyclic depsipeptides called didemnins isolated from Trididemnum species of tunicates which showed in vitro and in vivo antiviral properties against the viruses causing Rift Valley fever, Venezuelan equine encephalomyelitis and yellow fever. ${ }^{24)}$ But the most important contribution of the marine environment to this area was the isolation and characterization of arabinosyl nucleosides from the sponge Tethya cripta by Bergmann and Feeney used as models for the synthesis of ara-A (vidarabine) that has been used therapeutically against herpetic encephalitis since the late 1970's. ${ }^{25)}$ Other examples of products of semisynthetic modifications of the arabinosyl nucleosides are ara-C (cytarabine), acyclovir and azidothymidine (zidovudine) which are, nowadays, in clinical use. ${ }^{1)}$

In this report, we describe the antiviral evaluation of marine sponge extracts collected from the Brazilian coastline. This study is part of a collaborative work among several Brazilian institutions (Laboratório de Virologia Aplicada, Universidade Federal de Santa Catarina; Fundação Zoobotânica do Rio Grande do Sul; Departamento de Oceanografia, Universidade Federal de Pernambuco; Departamento de Sistemática e Ecologia, Universidade Federal da Paraíba; and Faculdade de Farmácia, Universidade Federal do Grande do Sul) for the collection and screening of Brazilian marine sponges for pharmacological activities, with the aim of identifying new sponge species and novel molecules with promising and potentially useful therapeutic activities. This paper is a continuation of a previously performed work with some of the sponges tested here. ${ }^{26)}$

\section{MATERIALS AND METHODS}

Sponges Sampling and Identification Sponge samples were collected manually from exposed and semi-exposed habitats, at depths of between 0.5 and $14 \mathrm{~m}$, from different locations on the Brazilian southeast and northern coastline. Taxonomic designation was based on scanning electron microscope studies and on skeletal slides and dissociated spicule mounts. Specimens of all materials were deposited in the collection from the Museu de Ciências Naturais-Porífera (MCNPOR) which belongs to Fundação Zoobotânica do Rio Grande do Sul, Brazil.

Extracts Preparation Aqueous extracts were produced by the following procedure: sponge materials were ground together with sand and water three times for $30 \mathrm{~min}$. The resulting extract (collected after each $30 \mathrm{~min}$ ) was subsequently filtered and freeze-dried. The remaining material was sequentially extracted five times with a methanol/toluene mixture $(3: 1, \mathrm{v} / \mathrm{v})$ by maceration over $5 \mathrm{~d}$. Each resulting extract was then filtered and concentrated in a rotavapor. ${ }^{26)}$ For the antiviral assays, both the aqueous and organic extracts were suspended in MEM Medium (Sigma) and 1\% DMSO (Nu- clear) at a concentration of $1000 \mu \mathrm{g} / \mathrm{ml}(\mathrm{w} / \mathrm{v})$. Table 1 shows the 40 extracts tested in this study.

Cell Cultures and Viruses The cell lines used were Vero cells (Adolpho Lutz Institute, Brazil), HEp-2 cells (University Federal of Rio de Janeiro/UFRJ, Brazil) and MA104 cells (Biological Sciences Institute, University of São Paulo/USP, Brazil). These cell lines were grown in MEM Medium (Sigma) supplemented with 10\% fetal bovine serum (FBS, Gibco BRL), penicillin G $(100 \mathrm{U} / \mathrm{ml})$, streptomycin $(100 \mu \mathrm{g} / \mathrm{ml})$ and amphotericin B $(0.025 \mathrm{mg} / \mathrm{ml})$ (Gibco BRL). The cell cultures were maintained in a humidified atmosphere under $5 \% \mathrm{CO}_{2}$ at $37^{\circ} \mathrm{C}$. The following viruses were used: Herpes Simplex Virus type 1 (HSV-1), KOS strain (Laboratory of Pharmacognosy, Faculty of Pharmacy, University of Rennes, France); human adenovirus serotype 5 (AdV-5) and simian rotavirus SA11 (RV-SA11) (both from Biological Sciences Institute, University of São Paulo/USP, Brazil). HSV-1 and AdV-5 were propagated in Vero and HEp-2 cells, respectively; RV-SA11 was propagated in MA104 cells in the presence of trypsin (Sigma, $5 \mu \mathrm{g} / \mathrm{ml}) .{ }^{27}$ ) Stock viruses were prepared as previously described, ${ }^{28)}$ and the infected cells supernatant fluids were harvested, titrated and stored at $-80^{\circ} \mathrm{C}$ until used. HSV-1 and AdV-5 titers were obtained by the plaque method and were expressed as plaque forming units per $\mathrm{ml}(\mathrm{pfu} / \mathrm{ml}){ }^{29)} \mathrm{RV}-\mathrm{SA} 11$ titer was obtained by immunofluorescence assay and expressed as focus forming units per $\mathrm{ml}(\mathrm{ffu} / \mathrm{ml}){ }^{30)}$

Cytotoxicity Evaluation The cell viability was evaluated by the 3-(4,5-dimethylthiazol-2-yl)-2,5-diphenyl tetrazolium bromide (MTT) method ${ }^{31,32)}$ with minor modifications.

Vero, HEp-2, and MA104 cell cultures $\left(2 \times 10^{5}\right.$ cells $\left./ \mathrm{ml}\right)$ were prepared in 96-well tissue culture plates. After a $24 \mathrm{~h}$ incubation period in a humidified atmosphere under $5 \% \mathrm{CO}_{2}$ at $37^{\circ} \mathrm{C}$, cell monolayer was confluent, the medium was removed from each well and replenished with $200 \mu \mathrm{l}$ of different concentrations of sponges extracts/per well $(1: 2)$ ranging from 7.81 to $1000 \mu \mathrm{g} / \mathrm{ml}$ prepared in MEM medium. For cell controls, $200 \mu \mathrm{l}$ of medium were added. After 4, 5 and $3 \mathrm{~d}$ of incubation, respectively, for Vero, HEp-2 and MA104 cells at $37^{\circ} \mathrm{C}$ at the same conditions described above, the medium was removed by suction from all wells and $50 \mu \mathrm{l}$ of MTT solution (Sigma, $1 \mathrm{mg} / \mathrm{ml}$ ) prepared in MEM medium were added to each well and the plates were incubated for $4 \mathrm{~h}$ at the same conditions described above. The MTT solution was removed without disturbing the cells by suction, and $100 \mu \mathrm{l}$ of DMSO were added to each well to dissolve formazan crystals. After gently shaking the plates for $10 \mathrm{~min}$, whereby crystals were completely dissolved, the absorbances were read on a multiwell spectrophotometer (Bio-Tek, Elx 800, U.S.A.) at $540 \mathrm{~nm}$. The percentages of cytotoxicity were calculated as $[(A-B) / A \times 100]$, where $A$ and $B$ are the absorbances of control and treated cells, respectively. For each sponge extract, the obtained $\mathrm{CC}_{50}$ value was defined as the concentration that reduced the absorbance of treated cells by $50 \%$ when compared to cell control.

Antiviral Assay The antiviral assays were also performed by MTT method, and technical details are described below.

Simultaneous Treatment Assay ${ }^{33)}$ : Vero, HEp-2 and MA104 cultures $\left(2 \times 10^{5}\right.$ cells $\left./ \mathrm{ml}\right)$ were prepared in 96 -well 
Table 1. Extracts of Marine Sponges Collected off the Brazilian Coast Examined in This Study

\begin{tabular}{|c|c|c|c|c|c|}
\hline Species & Collection number & Family & Authors & Geografic origin & Extracts tested \\
\hline Petromica citrina & MCN 3395 & Halichondriidae & Muricy et al., 2001 & $\mathrm{SC}$ & A \\
\hline Tedania ignis & MCN 3397 & Tedaniidae & Duchassaing and Michelotti, 1864 & SC & $\mathrm{O}+\mathrm{A}$ \\
\hline Dragmacidon reticulatus & MCN 3425 & Axinellidae & Ridley and Dendy, 1886 & $\mathrm{SC}$ & $\mathrm{O}+\mathrm{A}$ \\
\hline Polymastia janeirensis & MCN 3569 & Polymastidae & Boury-Esnault, 1973 & $\mathrm{SC}$ & $\mathrm{O}+\mathrm{A}$ \\
\hline Axinella aff. corrugata & MCN 3772 & Axinellidae & George and Wilson, 1919 & $\mathrm{SC}$ & $\mathrm{O}+\mathrm{A}$ \\
\hline Haliclona tubifera & MCN 3771 & Chalinidae & George and Wilson, 1919 & SC & A \\
\hline Niphates sp. & MCN 4263 & Chalinidae & & PB & A \\
\hline Haliclona sp. & MCN 5021 & Chalinidae & & $\mathrm{SC}$ & A \\
\hline Haliclona sp. & MCN 5148 & Chalinidae & & PE & A \\
\hline Mycale arcuiris & MCN 3984 & Mycalidae & Lerner and Hadju, 2002 & $\mathrm{SC}$ & A \\
\hline Cinachyrela alloclada & MCN 4264 & Tetillidae & Ulikczka, 1929 & PB & $\mathrm{O}+\mathrm{A}$ \\
\hline Cinachyrella $\mathrm{sp}$. & MCN 5157 & Tetillidae & & $\mathrm{PE}$ & A \\
\hline Cinachyrella alloclada & MCN 4659 & Tetillidae & Ulikczka, 1929 & PE & A \\
\hline Guitarra sepia. & MCN 4002 & Guitarridae & Lerner et al., 2004 & $\mathrm{SC}$ & $\mathrm{O}+\mathrm{A}$ \\
\hline Agelas sp.1 & MCN 4267 & Agelasidae & & PB & $\mathrm{O}+\mathrm{A}$ \\
\hline Agelas sp. 2 & MCN 4669 & Agelasidae & & PB & $\mathrm{O}+\mathrm{A}$ \\
\hline Protosuberites sp. & MCN 4660 & Suberitidae & & PE & $\mathrm{O}+\mathrm{A}$ \\
\hline Tethya sp. & MCN 4661 & Tethydae & & $\mathrm{PE}$ & A \\
\hline Cliona sp. & MCN 5070 & Clionaidae & & $\mathrm{SC}$ & A \\
\hline Cliona sp.1 & MCN 5143 & Clionaidae & & $\mathrm{PE}$ & A \\
\hline Cliona sp.2 & MCN 4662 & Clionaidae & & $\mathrm{PE}$ & A \\
\hline Halichondria sp. & MCN 4663 & Halicondriidae & & PE & A \\
\hline Halichondria sp.1 & MCN 5162 & Halicondriidae & & $\mathrm{PE}$ & A \\
\hline Halichondria sp.2 & MCN 5152 & Halicondriidae & & $\mathrm{PE}$ & A \\
\hline Chondrosia collectrix & MCN 4656 & Chondrillidae & Schmidt, 1862 & $\mathrm{PE}$ & $\mathrm{O}+\mathrm{A}$ \\
\hline Arenosclera sp. & MCN 5269 & Callyspongiidae & & $\mathrm{SC}$ & A \\
\hline Raspailia elegans & MCN 5058 & Raspailiidae & Boury-Esnault, 1973 & $\mathrm{SC}$ & A \\
\hline Suberites sp. & MCN 5147 & Suberitidae & & PE & A \\
\hline Placospongia cf. intermedia & MCN 5159 & Placospongiidae & & $\mathrm{PE}$ & A \\
\hline Placospongia cf. intermedia & MCN 4658 & Placospongiidae & & $\mathrm{PE}$ & A \\
\hline
\end{tabular}

$\mathrm{MCN}=$ Natural Science Museum; $\mathrm{A}=$ aqueous; $\mathrm{O}=$ organic; $\mathrm{SC}, \mathrm{PE}, \mathrm{PB}=$ Santa Catarina, Pernambuco and Paraiba States, respectively

tissue culture plates. After $24 \mathrm{~h}$ period of incubation in a humidified atmosphere under $5 \% \mathrm{CO}_{2}$ at $37^{\circ} \mathrm{C}$, cell monolayer was confluent, the medium was removed from each well and replenished with $100 \mu \mathrm{l} /$ well of non cytotoxic sponge extracts concentrations ( $\leq \mathrm{CC}_{50}$ values) and $100 \mu \mathrm{l} /$ well of each one of the following viruses $(\mathrm{MOI}=0.5)$ : HSV-1, KOS strain; AdV-5; and RV-SA11 previously treated with trypsin (5 $\mu \mathrm{g} / \mathrm{ml}$ ) at $37^{\circ} \mathrm{C}$ for $20 \mathrm{~min}$. Cells and viruses controls were added simultaneously. Plates were incubated for a period of time corresponding to four cycles of virus replication: $96 \mathrm{~h}$ for HSV-1, $140 \mathrm{~h}$ for AdV-5 and $72 \mathrm{~h}$ for RV-SA11. The same method used to evaluate cell viability with MTT as described above (item 2.4) was followed. The percentages of protection were calculated as $[(A-B) /(C-B) \times 100]$, where $A, B$ and $C$ indicate the absorbances of the sponge extract, virus and cell controls, respectively. The obtained $\mathrm{EC}_{50}$ value was defined as the concentration that reduced the absorbance of infected cells to $50 \%$ when compared to cell and virus controls. Acyclovir [9-(2-hydroxyethoxymethyl) guanosine, Sigma, 10 $\mu \mathrm{g} / \mathrm{ml}]$ was used as positive control for HSV-1 inhibition.

Pre Treatment Assay ${ }^{34)}$ : This assay was carried out to determine whether the sponge extracts inhibited viruses replication by affecting their adsorption or penetration. Vero, HEp- 2 and MA104 cultures $\left(2 \times 10^{5}\right.$ cells $\left./ \mathrm{ml}\right)$ were prepared in 96-well tissue culture plates. After a $24 \mathrm{~h}$ period of incubation, non cytotoxic concentrations $\left(\leq \mathrm{CC}_{50}\right)$ of the sponge extracts $(100 \mu$ l per well) were added to the cells and incubated for $15 \mathrm{~h}$ prior to virus infection $(100 \mu \mathrm{l}$ of each virus/well, MOI $=0.5$ ). The same method described above was used, as well as the $\mathrm{EC}_{50}$ values were calculated.
Post Treatment Assay ${ }^{35)}$ : This assay was performed to determine if the sponge extracts inhibited viruses replication by affecting one or more steps of their replication when viruses are already into the cells. The cells were prepared using the same method and after their incubation for $24 \mathrm{~h}$, the viruses $(\mathrm{MOI}=0.5)$ were added to the cells $(100 \mu \mathrm{l}$ of each virus/well) and remained during $2 \mathrm{~h}$ at $37^{\circ} \mathrm{C}$ prior to the addition of non cytotoxic concentrations ( $\leq \mathrm{CC}_{50}$ values) of the sponge extracts $(100 \mu \mathrm{l}$ per well). Before the addition of the tested extracts, viruses inocula were removed. The same method described above was used, as well as the $\mathrm{EC}_{50}$ values were calculated.

Data Analysis The $\mathrm{CC}_{50}$ and $\mathrm{EC}_{50}$ values were estimated from concentration-effect curves after linear regression analysis, and represent mean \pm standard error of the mean values of three independent experiments.

\section{RESULTS}

From the 40 tested sponge extracts (Table 1) 17 extracts showed antiviral action ( $\mathrm{SI}$ values $\geq 1.5 ; \mathrm{SI}=\mathrm{CC}_{50} / \mathrm{EC}_{50}$ ). Table 2 shows the results of in vitro evaluation of marine sponge extracts for their potential anti-herpetic, anti-adenovirus and anti-rotavirus activities. In relation to the in vitro evaluation of the anti-rotavirus activity only 10 extracts were tested because there were not enough amounts of the other extracts available to perform the anti-rotavirus evaluation. The results showed in Table 2 were obtained by using the first strategy described above (item 2.5.1). In this assay, the extracts were added to the cells at the same time of the 
Table 2. Results of the in Vitro Evaluation of Sponge Extracts (Simultaneous Treatment) for Their Potential Anti-herpetic (HSV-1, KOS Strain), Anti-adenovirus (AdV-5, Serotype 5), and Anti-rotavirus Activities (RV-SA11)

\begin{tabular}{|c|c|c|c|}
\hline Sponge extracts & HSV-1/KOS SI $\left(\mathrm{CC}_{50} / \mathrm{EC}_{50}\right)^{a)}$ & AdV-5 SI $\left(\mathrm{CC}_{50} / \mathrm{EC}_{50}\right)^{a)}$ & RV-SA11 SI $\left(\mathrm{CC}_{50} / \mathrm{EC}_{50}\right)^{a)}$ \\
\hline Petromica citrina-A & $2.0(580 / 277)$ & $4.5(534 / 117)$ & $\left(>1000 /^{b}\right)$ \\
\hline Tedania ignis-O & $2.0(500 / 257)$ & $1.6(225 / 136)$ & NT \\
\hline Tedania ignis- $\mathrm{A}$ & $\left(370 /^{b)}\right)$ & $3.3(413 / 124)$ & NT \\
\hline Dragmacidon reticulata-A & $1.7(>1000 / 595)$ & $\left(714 /^{b)}\right)$ & $\left(>1000 / /^{b)}\right)$ \\
\hline Axinella aff corrugata-A & $3.0(>1000 / 332)$ & $2.0(866 / 400)$ & $\left(>1000 / /^{b)}\right)$ \\
\hline Agelas sp.1-A & $\left(>1000 /{ }^{b}\right)$ & $4.5(>1000 / 225)$ & $\left(>1000 /{ }^{b)}\right)$ \\
\hline Agelas sp.2-A & $2.5(>1000 / 378)$ & $\left(>1000 /{ }^{b)}\right)$ & NT \\
\hline Agelas sp.2-O & $1.5(>1000 / 575)$ & $\left(810 /{ }^{b)}\right)$ & NT \\
\hline Tethya sp.-A & $2.5(>1000 / 425)$ & $1.8(415 / 230)$ & NT \\
\hline Polymastia janeirensis-O & $3.0(510 / 170)$ & $\left(464 / /^{b)}\right)$ & NT \\
\hline Polymastia janeirensis-A & $\left(436 /{ }^{b)}\right)$ & $\left(380^{/ b}\right)$ & $28.5(>1000 / 35)$ \\
\hline Cliona $\mathrm{sp} . \mathrm{-A}$ & $7.35(>1000 / 136)$ & $\left(750 /{ }^{b)}\right)$ & $\left(100 /^{b b}\right)$ \\
\hline Cliona sp.2-A & $\left(>1000 / /^{b)}\right)$ & $\left(283 /^{b}\right)$ & $9.0(>1000 / 111)$ \\
\hline Chondrosia collectrix-A & $2.0(640 / 334)$ & $\left(387 / /^{b)}\right)$ & NT \\
\hline Mycale arcuiris-A & $\left(535 /^{b)}\right)$ & $\left(407 /^{b)}\right)$ & $1.7(>1000 / 591)$ \\
\hline Haliclona sp.-A (PE) & $\left(>1000 / /^{b)}\right)$ & $1.5(>1000 / 637)$ & $27.0(>1000 / 367)$ \\
\hline Protosuberites sp.-A & $\left(>100 /^{b)}\right)$ & $\left(>1000 / /^{b)}\right)$ & $12.5(>1000 / 80)$ \\
\hline
\end{tabular}

Just the sponge extracts with SI values $\geq 1.5$ are shown in this table. $\mathrm{A}=$ aqueous extract; $\mathrm{O}=$ organic extract; $\mathrm{SI}=\left(\mathrm{CC} \mathrm{C}_{50} / \mathrm{EC} \mathrm{C}_{50}\right) ; \mathrm{NT}=$ not tested; $\mathrm{PE}=\mathrm{Pernambuco} \mathrm{State}$ a) The $\mathrm{CC}_{50}$ and $\mathrm{EC}_{50}$ values were presented as $\mu \mathrm{g} / \mathrm{ml}$. b) $\%$ of inhibition $<50 \%$, consequently the SI values were not calculated.

Table 3. Results of the Pre- and Post-treatments with the Sponge Extracts That Showed the Best Results When the Simultaneous Treatment Was Used, in Relation to HSV-1 (KOS Strain)

\begin{tabular}{llc}
\hline \hline \multirow{2}{*}{ Sponge extracts } & \multicolumn{1}{c}{$\mathrm{HSV}-1 \mathrm{SI}\left(\mathrm{CC}_{50} / \mathrm{EC}_{50}\right)^{a)}$ treatments } \\
\cline { 2 - 3 } & \multicolumn{1}{c}{ Pre- } & Post- \\
\hline Petromica citrina-A & $3.0(580 / 195)$ & $2.4(580 / 240)$ \\
Tedania ignis-O & $2.0(500 / 250)$ & $\left(500 /{ }^{b)}\right)$ \\
Dragmacidon reticulata-A & $5.0(>1000 / 200)$ & $\left(>1000 / /^{b)}\right)$ \\
Axinella aff corrugata-A & $5.0(>1000 / 200)$ & $\left(>1000 / /^{b}\right)$ \\
Agelas sp.2-A & $8.0(>1000 / 125)$ & $2.6(>1000 / 350)$ \\
Tethya sp.-A & $5.0(>1000 / 200)$ & $2.2(>1000 / 450)$ \\
\hline
\end{tabular}

$\mathrm{A}=$ aqueous extract; $\mathrm{O}=$ organic extract; $\mathrm{SI}=\left(\mathrm{CC}_{50} / \mathrm{EC}_{50}\right) . \quad$ a) The $\mathrm{CC}_{50}$ and $\mathrm{EC}_{50}$ values were presented as $\mu \mathrm{g} / \mathrm{ml}$. b) $\%$ of inhibition $<50 \%$, consequently the SI values were not calculated.

Table 4. Results of the Pre- and Post-treatments with the Sponge Extracts That Showed the Best Results When the Simultaneous Treatment Was Used, in Relation to AdV-5

\begin{tabular}{lll}
\hline \hline \multirow{2}{*}{ Sponge extracts } & \multicolumn{2}{c}{$\mathrm{AdV}-5 \mathrm{SI}\left(\mathrm{CC}_{50} / \mathrm{EC}_{50}\right)^{a)}$ treatments } \\
\cline { 2 - 3 } & \multicolumn{1}{c}{ Pre- } & \multicolumn{1}{c}{ Post- } \\
\hline Petromica citrina-A & $2.7(534 / 198)$ & $-\left(534 / /^{b)}\right)$ \\
Tedania ignis-O & $4.3(225 / 52)$ & $4.5(225 / 50)$ \\
Tedania ignis-A & $2.5(413 / 167)$ & $2.8(413 / 152)$ \\
Axinella aff corrugata-A & $7.0(866 / 125)$ & $2.5(866 / 346)$ \\
Agelas sp.1-A & $10.0(>1000 / 100)$ & $8.3(>1000 / 120)$ \\
Tethya sp.-A & $3.2(415 / 130)$ & $1.3(415 / 315)$
\end{tabular}

$\mathrm{A}=$ aqueous extract; $\mathrm{O}=$ organic extract; $\mathrm{SI}=\left(\mathrm{CC}_{50} / \mathrm{EC}_{50}\right)$. a) The $\mathrm{CC}_{50}$ and $\mathrm{EC}_{50}$ values were presented as $\mu \mathrm{g} / \mathrm{ml}$. b) $\%$ of inhibition $<50 \%$, consequently the SI values were not calculated.

viruses. When the extracts showed SI values $\geq 1.5$ by using this first evaluation strategy, and they were still available in enough quantities, two other strategies were used (itens 2.5.2 and 2.5.3). The results were shown in Tables 3, 4 and 5 for anti-herpetic, anti-adenovirus and anti-rotavirus evaluation, respectively.
Table 5. Results of the Pre- and Post-treatments with the Sponge Extracts That Showed the Best Results When the Simultaneous Treatment Was Used, in Relation to RV-SA11

\begin{tabular}{lcc}
\hline \hline \multirow{2}{*}{ Sponge extracts } & RV-SA11 SI $\left(\mathrm{CC}_{50} / \mathrm{EC}_{50}\right)^{a)}$ treatments \\
\cline { 2 - 3 } & Pre- & Post- \\
\hline Polymastia janeirensis-A & $\left(>125^{/ b)}\right)$ & $1.7(>125 / 83)$ \\
Cliona sp.2-A & $\left(>125^{b)}\right)$ & $3.0(>125 / 43)$ \\
Haliclona sp. (PE)-A & $\left(>250 /{ }^{b)}\right)$ & $1.4(>250 / 187)$ \\
\hline
\end{tabular}

$\mathrm{A}=$ aqueous extract; $\mathrm{O}=$ organic extract; $\mathrm{SI}=\left(\mathrm{CC}_{50} / \mathrm{EC}_{50}\right) ; \mathrm{PE}=$ Pernambuco State a) $\mathrm{The} \mathrm{CC}_{50}$ and $\mathrm{EC}_{50}$ values were presented as $\mu \mathrm{g} / \mathrm{ml}$. b) $\%$ of inhibition $<50 \%$, consequently the SI values were not calculated.

\section{DISCUSSION}

The following reasons can be used to explain the different results obtained with HSV-1/KOS, AdV-5 and RV-SA11: a) the specificity of compounds present in the tested extracts to viral or cellular receptors; these compounds could probable inhibit virus interaction with different receptors necessary to the adsorption and penetration of the viruses into the cells; $b$ ) the presence or absence of viral envelope. In HSV-1 the envelope is present while in AdV-5 and RV-SA11 viruses, it is not. It is well known that some compounds with antiviral activity have affinity with molecules of the viral envelope and that the infectivity of viruses depends on the integrity of its envelope ${ }^{36,37)}$; c) the genetic material of the viruses studied: the genomes of HSV-1 and AdV-5 viruses are composed by DNA, and RV-SA11 virus is composed by double stranded RNA. Therefore, the differences among the viruses studied could, in part, justify the different results obtained for each one of them.

The pre treatment assay was done in order to identify the extracts that act on viral adsorption blockage avoiding, consequently, virus penetration into the cells. ${ }^{34,35)}$ When this strategy was used, the extracts that demonstrated promising results could block the interaction between viral and cell 
Table 6. Detected Classes of Compounds Reported in the Reviewed Literature for the Marine Sponges Genus Which Showed Antiviral Activity in This Study

\begin{tabular}{|c|c|c|}
\hline Sponges genus & Classes of compounds & References \\
\hline \multirow[t]{2}{*}{ Genus Tedania } & Dicetopiperazines & Stierle et al., 1988 \\
\hline & Macrolides & Matsushima et al., 1999 \\
\hline \multirow[t]{2}{*}{ Genus Dragmacidon } & Phospholipids & Barnathan et al., 1996 \\
\hline & Sterols & Sjostrand et al., 1981 ${ }^{47)}$ \\
\hline Genus Axinella & Alkaloids & Duckworth et al., 2003 \\
\hline \multirow[t]{2}{*}{ Genus Agelas } & Alkaloids & Shen et al., 1998 $8^{49)}$; Assmann et al., 200150); Fujita et al., 2003 ${ }^{51)}$ \\
\hline & Phospholipids & Carballeira and Emiliano, $1993^{52)}$ \\
\hline Genus Tethya & Lipids & Smith and Djerassi, $1987^{53)}$; Lorenz et al., $1995^{54)}$ \\
\hline \multirow[t]{2}{*}{ Genus Polymastia } & Sterols & Faulkner, 2001 ${ }^{18)}$ \\
\hline & Tetrahidroxiamide & $\mathrm{Xu}$ and Zeng, $2000^{55)}$ \\
\hline Genus Cliona & Sterols - clionastatine & Fatorrusso et al., 2004 \\
\hline \multirow[t]{2}{*}{ Genus Chondrosia } & Phospholipids & Carballeira et al., $1993^{57)}$ \\
\hline & Macrolides & Shin et al., 2004 ${ }^{58)}$ \\
\hline \multirow[t]{3}{*}{ Genus Mycale } & Dihidroxidecanoid acid & Doshida et al., $1996^{59)}$ \\
\hline & Macrolides & Hood et al., 2001 ${ }^{60)}$ \\
\hline & Steroids & Antonov et al., 2003 ${ }^{61)}$ \\
\hline \multirow[t]{6}{*}{ Genus Haliclona } & Aminoalcohol & Faulkner, $2001^{18)}$ \\
\hline & Polyacetilenes & Faulkner, $2001^{18)}$ \\
\hline & Alkaloids & Volk and Kock, 2004 ${ }^{62)}$ \\
\hline & Steroids & Sperry and Crews, $1997^{63)}$ \\
\hline & Peptides & Sera et al., 2003 ${ }^{64)}$ \\
\hline & Macrolides & Erickson et al., 1997 \\
\hline Genus Protosuberites & Nitrogen compounds & Fleming, 199966) \\
\hline
\end{tabular}

membrane receptors. The results were more promising for the pre treatment in relation to HSV-1 and AdV-5 viruses, when compared to those for simultaneous and post treatments (Tables 3,4). This fact can be due to the probable presence of certain compounds that, recognizably, inhibit the viruses adsorption and penetration into the cell, such as peptides $^{38-41)}$; lipids ${ }^{6,42)}$; and alkaloids. ${ }^{39,43)}$ In fact, the majority of the sponge extracts that had demonstrated promising antiviral results are rich in these three groups of metabolites.

Table 6 shows the detected classes of compounds already described in the reviewed literature for the marine sponges genus which showed some antiviral activity in our study. Related compounds belonging to these groups of metabolites may be present in the tested extracts and/or could be even responsible for the antiviral activity described here, but further studies are necessary to confirm this hypothesis.

The pre treatment assay performed for RV-SA11 virus did not show significant antiviral activity (Table 5) demonstrating that these compounds did not affect viral adsorption and penetration. The results of the post treatment carried out with RV-SA11 virus showed SI values smaller than those obtained with simultaneous treatment (Table 5). This fact indicates that the compounds found in these extracts have less capacity to inhibit the late stages of rotavirus replication. The results for the post treatment of $\mathrm{HSV}-1$ with the extracts did not show promising results when compared to those obtained with simultaneous and pre treatments (Table 3 ).

In relation to AdV-5 virus, half of the extracts submitted to the post treatment demonstrated some antiviral activity when compared to those of simultaneous treatment (Table 4). The compounds of these extracts probably act on the inhibition of the late stages of the viral replication, but it could not be stated the real reason why the values of SI are higher in the post-treatment than in the simultaneous treatment. It is not possible that the effective compounds could be degradated in a short period of time. Although, due to the facts that in the post-treatment the viruses remain in contact with the cells for a limited period of time $(2 \mathrm{~h})$, and that the viruses were removed before the addition of the extracts, it is possible that in the case of the post-treatment the extracts could exert their action without interference of the non adsorbed viruses. However, it remains necessary to perform an evaluation in which the extracts will be added in different times after the viral adsorption.

\section{CONCLUSIONS}

According to the results obtained in the present study, the extracts that presented the most promising results were: for HSV-1 - the aqueous extracts of Cliona sp., Agelas sp. 2 and Tethya sp.; for AdV-5 - the aqueous extracts of Agelas sp. and Axinella aff corrugata and the organic extract of Tedania ignis; and for RV-SA11 - the aqueous extracts of Haliclona sp.2, Polymastia janeirensis and Protosuberites sp.

These extracts deserve a special attention in further studies such as characterization of the active compounds and new antiviral assays.

Acknowledgments A. T. Henriques, C. R. M. Barardi and C. M. O. Simões are grateful to Conselho Nacional de Desenvolvimento Científico e Tecnológico/CNPq (Brazil) for their research fellowships, and J. M. Kratz for his BIC/CNPq fellowship. This work was supported by a grant from $\mathrm{CNPq}$ $(472337 / 2003-3)$

\section{REFERENCES}

1) De Clercq E., J. Clin. Virol., 30, $73-89$ (2004).

2) Celum C. L., Herpes, 11, 36- 45 (2004).

3) Baulfor H. H., N. Engl. J. Med., 340, 1255-1268 (1999).

4) Larder B. A., Darby G., Richman D. D., Science, 243, 1731-1734 (1989).

5) Wiedbrauk D. L., Johnston S. L. G., "Manual of Clinical Virology," 
Rave, New York, 1992.

6) White D. O., Fenner F. J., "Medical Virology," Academic Press, San Diego, 1994.

7) Che C., Drug Develop. Res., 23, 201-218 (1991).

8) Hudson J. B., Towers G. H. N., Drugs Future, 24, 295-320 (1999).

9) Harvey A. L., Trends Pharmacol. Sci., 20, 196-198 (1999).

10) Abad M. J., Guerra J. A., Bermejo P., Irurzun A., Carrasco L., Phytother. Res., 14, 604-607 (2000).

11) Bernan V. S., Greenstein M., Maiese W. M., Appl. Microbiol., 43, 5790 (1997).

12) Blunt J. W., Copp B. R., Munro M. H., Northcote P. T., Prinsep M. R., Nat. Prod. Rep., 20, 1-48 (2003).

13) Blunt J. W., Copp B. R., Munro M. H., Northcote P. T., Prinsep M. R., Nat. Prod. Rep., 21, 1-49 (2004).

14) Donia M., Hamann M. T., Lancet Infect. Dis., 3, 338-348 (2003).

15) Faulkner D. J., Nat. Prod. Rep., 11, 355-394 (1994).

16) Faulkner D. J., Nat. Prod. Rep., 15, 113-158 (1998)

17) Faulkner D. J., Nat. Prod. Rep., 17, 7-55 (2000).

18) Faulkner D. J., Nat. Prod. Rep., 18, 1-49 (2001).

19) Faulkner D. J., Nat. Prod. Rep., 19, 1—48 (2002)

20) Mayer A. M., Hamann M. T., Comp. Biochem. Physiol. C, 132, 315339 (2002).

21) Mayer A. M., Hamann M. T., Mar. Biotechnol., 6, 37-52 (2004).

22) Sarin P. S., Sun D., Thornton A., Muller W. E., J. Natl. Cancer Inst., 78, 663-666 (1987).

23) Rinehart K. L., Shield L. S., Cohens-Parsons M., "Pharmaceutical and Bioactive Natural Products," Vol. 1., ed. by Attaway D. H., Zaborsky O. R., Plenum Press, New York, 1993, pp. 309-342.

24) Vera M. D., Joullie M. M., Med. Res. Rev., 22, 102-145 (2002).

25) Bergmann W., Feeney R. J., J. Org. Chem., 16, 981—987 (1951).

26) Monks R. N., Lerner C., Henriques A. T., Farias M. F., Shapoval A., Suyenaga E. E., Rocha B. A., Shawartsmann G., Mothes B., J. Exp. Mar. Biol. Ecol., 281, 1-12 (2002).

27) Estes M. K., Graham D. Y., Mason B. B., J. Virol., 39, 879-888 (1981).

28) Simoes C. M. O., Amoros M., Girre L., Phytother. Res., 21, 317-325 (1999).

29) Burlenson F. G., Chamberts T. M., Wiedbrauk D. L., "Virology: A Laboratory Manual," Academic Press, San Diego, 1992.

30) Barardi C. R. M., Emslie K. R., Vesey G., Williams K. L., J. Virol. Methods, 74, 31-37 (1998).

31) Mossmann T., J. Immunol. Methods, 65, 55-63 (1983).

32) Sieuwerts A., Klijn J. G. M., Peters H. A., Foekens J. A., Eur. J. Clin. Chem. Clin. Biochem., 33, 813-823 (1995).

33) Takeuchi H., Baba M., Shigeta S., J. Virol. Methods, 33, 61-71 (1991).

34) Chou T. C., Talalay P., Adv. Enzyme Regul., 22, 27-55 (1984).

35) Hudson J. B., "Antiviral Compounds from Plants," CRC Press, Boca Raton, 1990.

36) Tang J., Colacino J. M., Larsen S. H., Spitzer W., Antiviral Res., 13, $313-325(1990)$

37) Srinivas R. V., Birkedal B., Owens R. J., Anantharamaiah G. M., Segrest J. P., Compans R. W., Virology, 176, 48-57 (1990).
38) Damonte E. B., Rev. Argent Microbiol., 28, 204-216 (1996).

39) Castilla V., Barquero A. A., Mersich S. E., Coto C. E., Int. J. Antimicrob. Agents, 10, 37-75 (1998).

40) Pereira H. S., Leao-Ferreira L. R., Moussatche N., Teixeira V. L., Cavalcanti D. N., Costa L. J., Diaz R., Frugulhetti I. C., Int. J. Antimicrob. Agents, 64, 69-76 (2004).

41) Raulin J., Lipids, 35, 123-130 (2000).

42) Morris-Natschke S. L., Ishaq K. S., Kucera L. S., Abbr. Curr. Pharm. Des., 9, 1441-1451 (2003).

43) Wittels M., Spear P. G., Virus Res., 18, 271-290 (1991).

44) Stierle A. C., Cardellina I. J. H., Singleton F. L., Experientia, 44, 1021 (1988).

45) Matsushima T., Mori M., Zheng B. Z., Maeda H., Nakajima N., Uenishi J., Yonemitso O., Chem. Pharm. Bull., 47, 308-321 (1999).

46) Barnathan G., Kornprobst J., Doumenq P., Mirallis J., Lipids, 31, 193-200 (1996).

47) Sjostrand U., Kornprobst J., Djerassi C., Steroids, 38, 355-364 (1981).

48) Duckworth A. R., Samples G. A., Wright A. E., Pomponi S. A., Mar Biotechnol., 5, 519-527 (2003).

49) Shen X., Perry T. L., Dunbar C. D., Kelly-Borges M., Hamann M. T., J. Nat. Prod., 61, 1302-1303 (1998).

50) Assmann M., Zea S., Kock M., J. Nat. Prod., 64, 1593-1595 (2001).

51) Fujita M., Nakao Y., Matsunaga S., Seiki M., Itoh Y., Yamashita J., Van Soest R. W., Fusetani N., J. Am. Chem. Soc., 125, 15700-15701 (2003).

52) Carballeira N. M., Emiliano A., Lipids, 28, 763-766 (1993).

53) Smith G. M., Djerassi C., Lipids, 22, 236-240 (1987).

54) Lorenz B., Batel R., Bachinski N., Muller W. E., Schroder H. C., Biochim. Biophys. Acta, 1245, 17-28 (1995).

55) Xu S., Zeng L., Zhong Yao Cai, 23, 533-535 (2000).

56) Fattorusso E., Taglialatela-Scafati O., Petrucci F., Bavestrello G., Calcinai B., Cerrano C., Di Meglio P., Ianaro A., Org. Lett., 13, 16331635 (2004).

57) Carballeira N. M., Reyes E. D., Shalabi F., J. Nat. Prod., 56, 763-766 (1993).

58) Shin J., Lee H. S., Kim J. Y., Shin H. J., Ahn J. W., Paul V. J., J. Nat. Prod., 67, 1889-1892 (2004).

59) Doshida J., Hasegawa H., Onuki H., Shimidzu N., J. Antibiot., 49, 1105-1109 (1996).

60) Hood K. A., Backstrom B. T., West L. M., Northcote P. T., Berridge M. V., Miller J. H., Anticancer Drug Des., 16, 155-166 (2001).

61) Antonov A. S., Afiyatullov S., Kalinovsky A. I., Ponomarenko L. P., Dmitrenok P. S., Aminin D. L., Agafonova I. G., Stonik V. A., J. Nat. Prod., 66, 1082-1088 (2003).

62) Volk C. A., Kock M., Org. Biomol. Chem., 2, 1827-1830 (2004).

63) Sperry S., Crews P., J. Nat. Prod., 60, 29-32 (1997).

64) Sera Y., Adachi K., Fujii K., Shizuri Y., J. Nat. Prod., 66, 719-721 (2003).

65) Erickson K. L., Beutler J. A., Carbellina I. J. H., Boyd M. R., J. Org. Chem., 62, 8188-8192 (1997).

66) Fleming F. F., J. Nat. Prod., 16, 597-606 (1999). 